\title{
Sciendo
}

DOI: $10.2478 /$ pts-2018-0021

\section{STUDY OF THE OPERATIONAL PROPERTIES OF BISTABLE SMECTIC-A LIQUID CRYSTAL DISPLAYS}

\author{
M. Maltisovs ${ }^{1,2}$, K. Krumins ', A. Ozols ', D. Pikulins ${ }^{2}$ \\ 'EuroLCDs Ltd., VATP-2, Ventspils, LV-3602, LATVIA \\ E-mail: matiss.maltisovs@gmail.com \\ 2Institute of Radioelectronics, Riga Technical University, \\ 12 Azenes Str., Riga, LV-1048, LATVIA
}

\begin{abstract}
Nowadays liquid crystal display (LCD) is an integral part of humans' everyday life. High demand for new and innovative LCD products force LCD industry to develop and implement new types of LCDs. Bistable smectic-A $(\mathrm{SmA}) \mathrm{LCD}$ is one of the most promising devices for smart glass applications due to long-term bistability, low haze at clear state, low transmittance at scatter state and low power consumption.

The study describes the most relevant conclusions obtained from frequency response testing and electric current measurements of bistable SmA LCD samples. Bistable LCDs have two states: opaque (light scattering state) and focal conic (transparent state). Switching between clear and scatter states and vice versa is a frequency dependant process. The conducted research on bistable SmA LC frequency response provides important knowledge about operation principles of the smart glass devices.
\end{abstract}

Keywords: bistable, frequency response, liquid crystal displays, smart glass, smectic- $A$

\section{INTRODUCTION}

Smart or switchable glass is glass with voltage dependant optical properties, which can be altered if specific electrical signals are applied to the glass. The main advantages of smart glass are the following:

- $\quad$ privacy - a fast state change from clear to scattering state and vice versa, low transmittance in opaque state, ability to replace curtains, shutter blinds, drapes;

- cost savings - no need for additional cleaning equipment, saving costs for heating, air-conditioning and lighting, avoiding the costs of installing and maintaining motorized light screens, blinds or curtains;

- UV protection - blocks $>98 \%$ of UV rays; 
- display and advertising - can be used as a projection screen when switched to the scatter state.

Smart glass technologies include electrochromic, suspended particle and polymer dispersed liquid crystal (PDLC) devices. Each of these types has different working principles, advantages, and disadvantages.

Electrochromic smart glass is the most popular - currently it utilizes an electrochromic film with an ion storage layer and ion conductor placed between two transparent sheets. An electric potential initiates a redox reaction of the electrochromic film transitioning the colour and the transparency of the smart glass [1].

Suspended particle smart glass has needle shaped particles suspended within an organic gel placed between two electrodes. In its off state (scattered), the particles are randomly dispersed and have low light transmittance. Once a voltage is applied, the needle particles will orient themselves to allow for light to pass through [1].

PDLC smart glass works similarly to the suspended particle variety. However, in PDLC smart glass, the central layer is a liquid crystal placed within a polymer matrix between electrodes. Similar in behaviour to the suspended particles, in the off (scattering) state the liquid crystals are randomly dispersed and have low light transmittance. When voltage is applied and an electric field is created, the liquid crystals orient themselves allowing light to pass through. PDLC film appears milky white due to the refractive index mismatch encountered by incoming light at the liquid crystal/polymer interface [1].

Bistable SmA liquid crystal displays differ from the above mentioned with lower power consumption due to the need for an electric field only during switching between states [2], [3]. For example, PDLC, Electrochromic and Suspended particle smart glass devices need an electric field to sustain one or both states, but bistable devices can sustain both states due to very high LC viscosity. SmA LC formulation also offers better optical properties $(<87 \%$ transmittance in the transparent state and $<1.7 \%$ in the scattering state) than PDLC $(<41 \%$ transmittance in the transparent state and $<23 \%$ in the scattering state) [4].

Existing studies do not provide detailed information on bistable SmA LC operational properties [5], [6]. Contrary to a majority of studies that have been conducted using small samples $<50 \times 50 \mathrm{~mm}$, the present research is based on $300 \times 400 \mathrm{~mm}$ large bistable SmA LC devices. The main goal is to determine the most suitable frequencies for switching the bistable LCDs to transparent and scattering states, i.e., frequencies that provide the highest light transmittance at the transparent state and the lowest light transmittance at the scattering state, taking into account the switching speed.

\section{EXPERIMENTAL PART}

A total of three different experimental series have been performed. For these experiments, two different types of bistable SmA LCDs have been manufactured. Both types have $300 \times 400 \mathrm{~mm}$ outer dimensions and active area equally divided into 8 pixels (one pixel is $95 \times 275 \mathrm{~mm}$ ), which can be switched individually or as a single 
unit if they are connected in parallel [7], [8]. To maintain a constant cell gap, $15 \mu \mathrm{m}$ plastic ball spacers with density of $10 \mathrm{pcs} / \mathrm{mm}^{2}$ have been used. LC has been supplied by Dow Corning Corporation [9], [10]. The main difference between the two LCD types used for these experiments lies in the dielectric (isolation) coating application procedure: for half of the devices the dielectric coating Silicon dioxide $\left(\mathrm{SiO}_{2}\right)$ has been applied before Indium tin oxide (ITO) ablation process and for other half - dielectric coating has been applied after ITO ablation. Contacts have been soldered on top and bottom electrodes (see Figs. 1, 2).

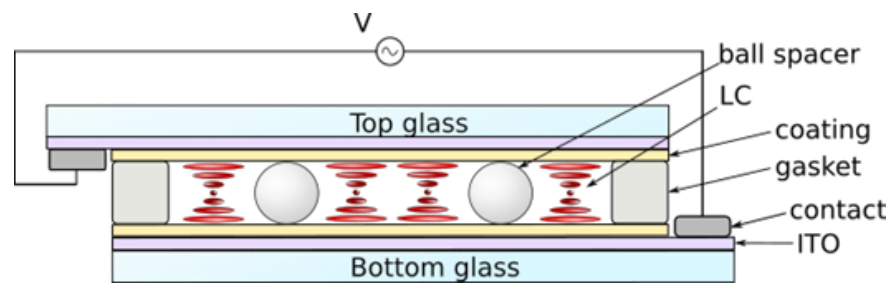

Fig. 1. Schematic picture of LC cell: cross-section [11].

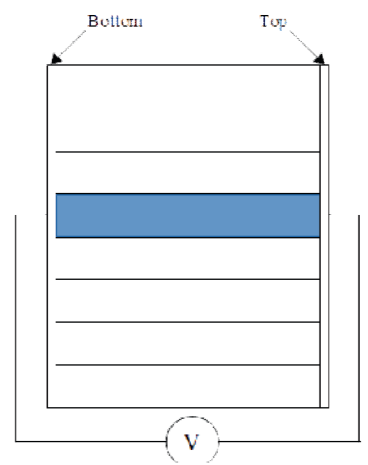

Fig. 2. Schematic picture of LC cell - top view.

Three samples from each display type have been used in these experiments. The first experiment has been devoted to obtaining the frequency response of LC cell. The reference frequencies $-1 \mathrm{kHz}$ frequency for switching to the transparent state and $50 \mathrm{~Hz}$ frequency for switching to the scattering state - have been chosen on the basis of the LC manufacturer's recommendations. The operating voltage $13 \mathrm{~V} /$ $\mu \mathrm{m}$ has been determined in other experiments. Experimental setup, shown in Fig. 3, consists of:

- $\quad$ alternating high-voltage (AHV) source, which provides a necessary voltage level for creating an electric field to switch the samples;

- optical measurement platform (OPMP), allowing the measurements of light transmission and switching speed;

- white LED, used as a light source, photodiode VTB-1013BH with maximized response through the visible part of the spectrum utilised as light detector;

- Ocean Optics laboratory-grade optical fibre patch cords as light guides. 


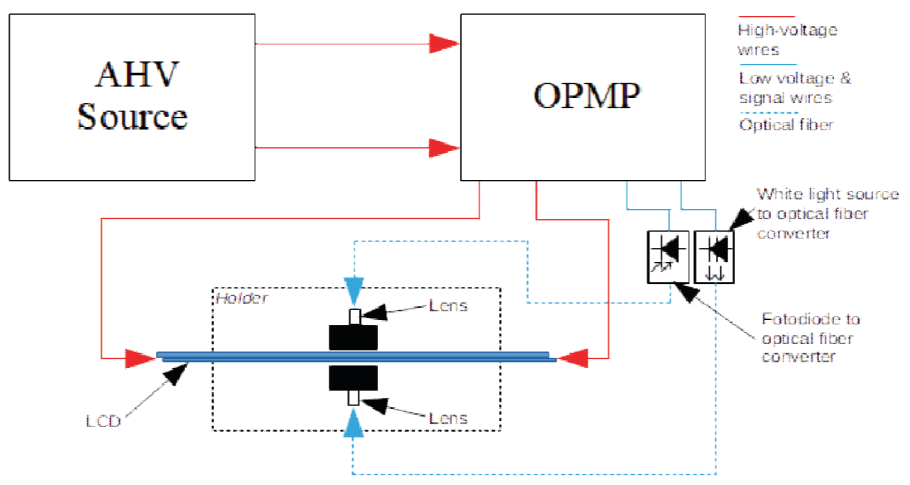

Fig. 3. Simplified schematic of frequency response measurement setup.

The second and third experiments have been carried out to obtain data on the most important electrical parameters of bistable SmA LCDs.

The data on optimised switching frequencies for both states obtained within the first experiment have been used to switch differently sized display areas of the LCD samples and measure voltage on the LCD and consumed electric power for a full display area, 1/2,1/4 and 1/8 of the display area. Experimental setup for the second and third experiments is depicted in Fig. 4. Difference between both experiments is in additional external resistors, which are used to limit the display current during the third experiment. For the current limitation, 10 different external metal oxide film resistors with resistances ranging from $8.2 \mathrm{Ohm}$ to $330 \mathrm{Ohm}$ (according to the E24 standard) have been used. This experiment has allowed determining the minimal required current for fully switching display from the transparent state to the scattering state and vice versa. The fourth test series have been conducted in order to compare the data from the second experiment to the voltage and consumed power measurements obtained for the SmA LC manufacturer's recommended frequencies.

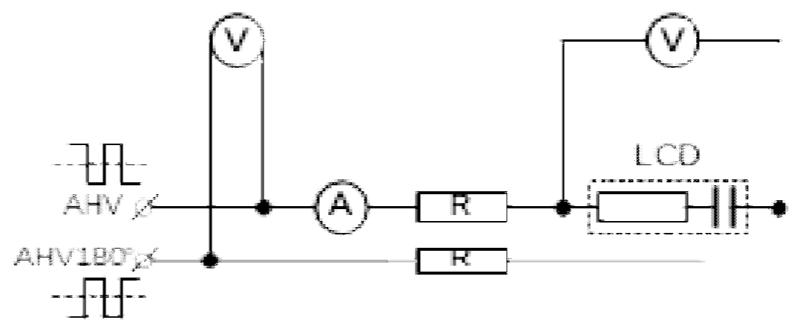

Fig. 4. Experimental setup for display current limitation and measurement.

\section{RESULTS AND DISCUSSION}

The dependence of driving frequency on light transmittance of bistable SmA LCD is shown in Fig. 5. The blue curve represents switching from the transparent to scattering state and the orange curve - switching from the scattering to trans- 
parent state. Frequency range for switching to the scattering state is very narrow $(10 \mathrm{~Hz}-60 \mathrm{~Hz})$ compared to the frequency range for switching to the transparent state $(200 \mathrm{~Hz}-1.5 \mathrm{kHz})$. The peak transmittance for switching to the transparent state can be obtained only in the frequency range between $500 \mathrm{~Hz}$ and $1 \mathrm{kHz}$.

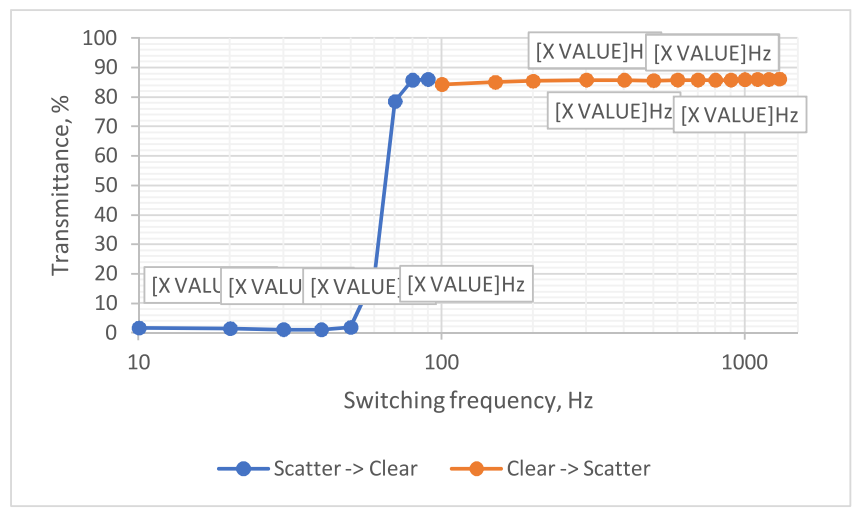

Fig. 5. Light transmittance at different driving frequencies.

More detailed graph showing the frequency range for switching to the scattering state, incorporating another important design parameter - switching speed (see orange curve), is shown in Fig. 6. It can be seen that the lowest switching speed and light transmittance can be achieved in the frequency range between $20 \mathrm{~Hz}-30 \mathrm{~Hz}$.

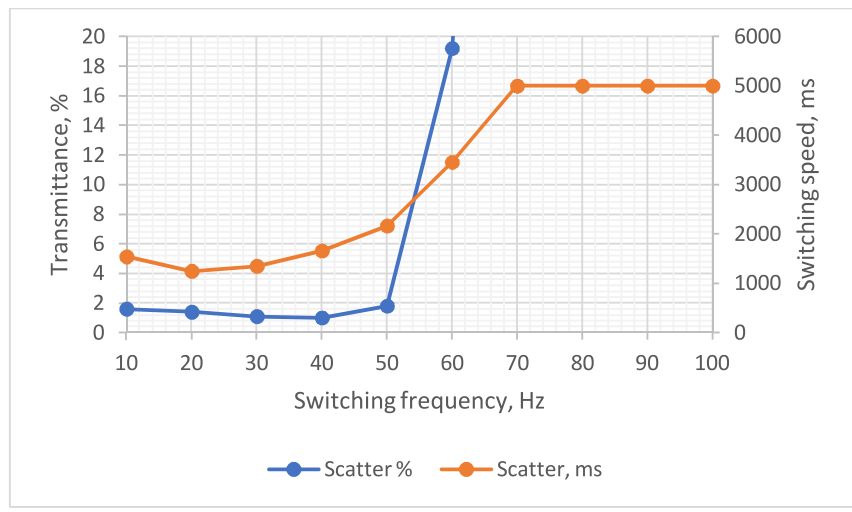

Fig. 6. Switching speed (orange) and light transmittance (blue) at different driving frequencies during transition to the scattering state.

The corresponding detailed graph showing the frequency range for switching to the transparent state is demonstrated in Fig 7. Light transmittance (blue) remains relatively constant (about $86 \%$ ) across most of the driving frequencies and switching speed (orange) reaches the lowest points around $116 \mathrm{~ms}-120 \mathrm{~ms}$ at the frequency range between $400 \mathrm{~Hz}$ and $700 \mathrm{~Hz}$. Thus, this region could be the most suitable for switching to the transparent state. 


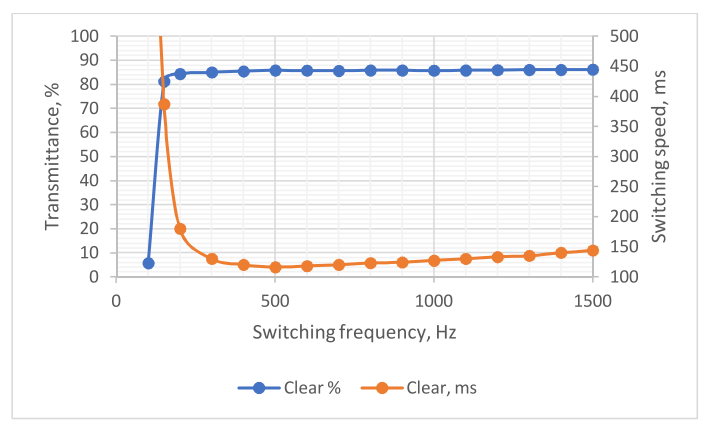

Fig. 7. Switching speed (orange) and light transmittance (blue) at different driving frequencies during transition to the scattering state.

During the second and third experiments, the consumed RMS current for differently sized display areas has been measured. The size of the switchable display area has been adjusted by connecting adjacent pixels in parallel. From the obtained data, the consumed RMS power has been calculated for all six tested displays, which is shown in Fig. 8. The power consumption increases exponentially depending on the number of pixels being used. The largest power consumption can be observed during transition to the transparent state when the whole display area is switched.

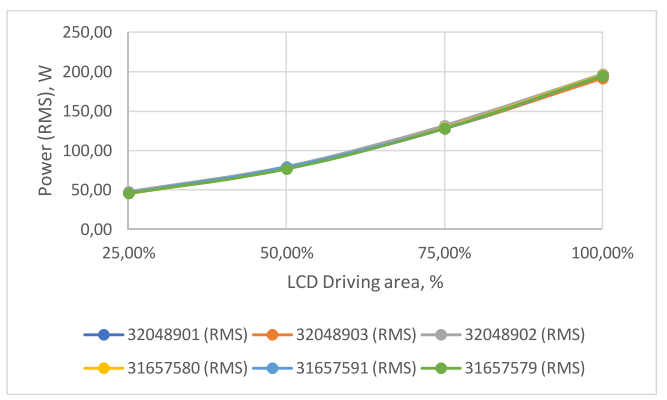

Fig. 8. Consumed RMS power depending on the size of the switched display area.

Current measurements with additional current limiting resistors for unit 32048903 (randomly chosen due to the obtained data similarity) are shown in Fig. 9. On the basis of the obtained results, it can be concluded that it is necessary to provide LCD with at least 0.9 A driving current to switch the whole display area from the scattering to transparent state and obtain $>85 \%$ light transmission.

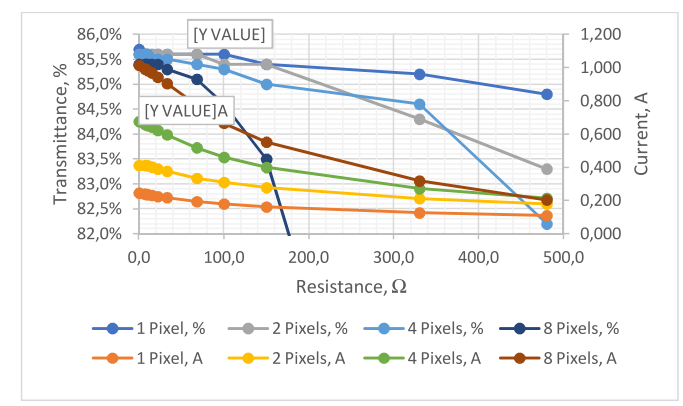

Fig. 9. Units 32048903 current measurements with current limiting resistors. 
Additional power consumption measurements have been performed with $50 \mathrm{~Hz} / 1 \mathrm{kHz}$ and $30 \mathrm{~Hz} / 600 \mathrm{~Hz}$ frequencies. Comparison between $600 \mathrm{~Hz}$ and $1 \mathrm{kHz}$ can be seen in Table 1, between $30 \mathrm{~Hz}$ and $50 \mathrm{~Hz}$ in Table 2. Significant improvements can be obtained in RMS current and RMS power by changing frequencies for both switching states.

Table 1

Consumed Power Comparison between $600 \mathrm{~Hz}$ and $1 \mathrm{kHz}$

\begin{tabular}{|c|c|c|c|c|c|c|}
\hline $\begin{array}{l}\text { Driving } \\
\text { frequency }\end{array}$ & Voltage & Peak current & RMS current & Peak power & RMS power & $\begin{array}{c}\text { Transmit- } \\
\text { tance }\end{array}$ \\
\hline $600 \mathrm{~Hz}$ & $190 \mathrm{~V}$ & $3.12 \mathrm{~A}$ & $1.03 \mathrm{~A}$ & $588.21 \mathrm{~W}$ & $194.42 \mathrm{~W}$ & $85.1 \%$ \\
\hline $1 \mathrm{kHz}$ & $190 \mathrm{~V}$ & $3.14 \mathrm{~A}$ & $1.33 \mathrm{~A}$ & $590.74 \mathrm{~W}$ & $249.94 \mathrm{~W}$ & $85.0 \%$ \\
\hline \multicolumn{2}{|c|}{ Improvement: } & $0 \%$ & $22 \%$ & $0 \%$ & $22 \%$ & \\
\hline
\end{tabular}

Table 2

Consumed Power Comparison between $30 \mathrm{~Hz}$ and $50 \mathrm{~Hz}$

\begin{tabular}{|c|c|c|c|c|c|c|}
\hline $\begin{array}{c}\text { Driving } \\
\text { frequency }\end{array}$ & Voltage & Peak current & RMS current & Peak power & RMS power & $\begin{array}{c}\text { Transmit- } \\
\text { tance }\end{array}$ \\
\hline $30 \mathrm{~Hz}$ & $190 \mathrm{~V}$ & $3.10 \mathrm{~A}$ & $0.26 \mathrm{~A}$ & $581.13 \mathrm{~W}$ & $49.29 \mathrm{~W}$ & $1.5 \%$ \\
\hline $50 \mathrm{~Hz}$ & $190 \mathrm{~V}$ & $3.09 \mathrm{~A}$ & $0.29 \mathrm{~A}$ & $579.92 \mathrm{~W}$ & $55.05 \mathrm{~W}$ & $1.7 \%$ \\
\hline \multicolumn{2}{r}{ Improvement: } & $0 \%$ & $10 \%$ & $0 \%$ & $10 \%$ & \multicolumn{2}{c}{$10 \%$}
\end{tabular}

\section{CONCLUSIONS}

The experimentally obtained operation parameters of large size 300x400 mm bistable smectic-A liquid crystal display samples have been presented in the paper.

Frequency response studies show that reducing the driving frequencies for transition to both the transparent state and the scattering state gives significant improvements in power consumption of the bistable devices. Reducing the driving frequency from $1 \mathrm{kHz}$ to $600 \mathrm{~Hz}$ (for transition to the transparent state) reduces the RMS current by $22 \%$, but reducing the driving frequency from $50 \mathrm{~Hz}$ to $30 \mathrm{~Hz}$ (for transition to the scattering state) reduces the power consumption by $10 \%$. In addition to power savings, the switching speed for both states has also improved, i.e., switching speed from the transparent to scattering state decreased from $\sim 2100 \mathrm{~ms}$ to $\sim 1300 \mathrm{~ms}$ (48 \%), from the scattering to transparent state - from $\sim 127 \mathrm{~ms}$ to $\sim 118 \mathrm{~ms}$ (7\%).

Power measurements for $1 \mathrm{px}, 2 \mathrm{px}, 4 \mathrm{px}$ and $8 \mathrm{px}$ give information about correlation between power consumption and the size of the drivable display area and opportunity to predict power consumption for new LCD patterning designs. The obtained RMS power consumption increases exponentially, i.e., $2 \mathrm{px}$ (25\% of display area) consumed power is $\sim 48 \mathrm{~W}, 4 \mathrm{px}(50 \%) \sim 80 \mathrm{~W}, 6 \mathrm{px}(75 \%) \sim 130 \mathrm{~W}$ and $8 \mathrm{px}$ $(100 \%) \sim 198 \mathrm{~W}$.

By gradually limiting the switching current, it has been concluded that switching the whole LCD area from the scattering state to the transparent state requires at least $170 \mathrm{~W}$ RMS power and at least $25 \mathrm{~W}$ to switch only $1 \mathrm{px}$. The highest power consumption can be observed during transition from the scattering to transparent 
state due to high switching frequency; therefore, it is very important to investigate the behaviour of liquid crystal within its operating frequency range.

Further research will be focused on additional experiments with bistable smectic-A liquid crystal displays due to unknown behaviour in long-term functionality, including experiments with different coating materials, long-term switching tests to understand degradation boundaries for LC and LCD, driving experiments where LCDs are connected in series with one AHV power source, etc.

\section{REFERENCES}

1. Wong, K. V., \& Chan, R. (2013). Smart glass and its potential in energy savings. Journal of Energy Resources Technology, 136(1), 12002. https://doi.org/10.1115/1.4024768

2. Goodby, J. W., Collings, P. J., Kato, T., Tschierske, C., Gleeson, H. F., \& Raynes, P. (2014b). Handbook of liquid crystals. Volume 2: Physical properties and phase behavior of liquid crystals. Boschstr. 12, 69469 Weinheim, Germany: Wiley-VCH Verlag \& Co. KGaA. Available at https:/www.wiley.com/en-lv/ Handbook+of+Liquid+Crystals $\% 2 \mathrm{C}+8+$ Volume + Set $\% 2 \mathrm{C}+2 \mathrm{nd}+$ Edition p-9783527327737

3. Goodby, J. W., Collings, P. J., Kato, T., Tschierske, C., Gleeson, H. F., \& Raynes, P. (2014a). Handbook of liquid crystals. Volume 8: Applications of liquid crystals. Germany: Wiley-VCH Verlag \& Co. KGaA. Available at https:/www.wiley.com/en-lv/Han dbook + of + Liquid+Crystals $\% 2 C+8+$ Volume + Set $\% 2 C+2$ nd+Edition-p-9783527327737

4. Ghosh, A., \& Mallick, T. K. (2018). Evaluation of optical properties and protection factors of a PDLC switchable glazing for low energy building integration. Solar Energy Materials and Solar Cells, 176, 391-396. https://doi.org/10.1016/j.solmat.2017.10.026

5. Coates, D., Crossland, W. A., Morrisy, J. H., \& Needham, B. (1978). Electrically induced scattering textures in smectic a phases and their electrical reversal. Journal of Physics D: Applied Physics, 11(14), 2025-2034. https://doi.org/10.1088/0022-3727/11/14/012

6. Gardiner, D. J., \& Coles, H. J. (2007). Enhancing lifetime in a bistable smectic A liquid crystal device. Journal of Physics D: Applied Physics, 40(4), 977-981. https://doi. org/10.1088/0022-3727/40/4/009

7. Lueder, E. (2010). Liquid crystal displays: Addressing schemes and electro-optical effects (2nd ed.). UK: John Wiley and Sons, Ltd. Available at https://www.wiley.com/enlv/Liquid+Crystal+Displays\%3A+Addressing+Schemes+and+Electro+Optical+Effects $\% 2 \mathrm{C}+2$ nd+Edition-p-9780470688182

8. Cristaldi, D. J. R., Pennisi, S., \& Pulvirenti, F. (2009). Liquid crystal display drivers: Techniques and circuits (1st ed.). Springer Science+Business Media B.V. https://doi. org/10.1007/978-90-481-2255-4

9. Hannington, J. P., Clapp, T. V., Nishida, F., King, R. K., Farooq, O., Grassman, M., ... Pivnenko, M. (2013). Oligosiloxane modified liquid crystal formulations and devices using same. European patent.

10. Clapp, T. V., Crossland, W. A., Davey, A. B., Grassman, M., Hannington, J. P., King, R. $\mathrm{K} ., \ldots \mathrm{Xu}, \mathrm{H}$. (2011). Liquid crystal formulations and structures for smectic A optical devices. Patent. Available at http://www.dowcorning.com/content/paintink/paintinkresin/ default.aspx

11. Mozolevskis, G., Ozols, A., Nitiss, E., Linina, E., Tokmakov, A., \& Rutkis, M. (2015). Reduction of electric breakdown voltage in lc switching shutters. Latvian Journal of Physics and Technical Sciences, 52(5), 47-57. https://doi.org/10.1515/lpts-2015-0028 


\title{
BISTABILO SMECTIC-A ŠKSIDRO KRISTĀLU DISPLEJU \\ DARBĪBAS PARAMETRU IZPĒTE
}

\author{
M. Maltisovs, K. Krūminšs, A. Ozols, D. Pikuḷins
}

Kopsavilkums

Cilvēku ikdiena bez šksidro kristālu displeju (LCD) tehnoloǵijām nav iedomājama. Augstais pieprasījums pēc jauniem un inovatīviem LCD produktiem piespiež industriju izstrādāt un ieviest jaunus LCD model̦us. Bistabilie SmecticA (SmA) LCD ir viena no daudzsološākajām tehnologiijām gudro stiklu produktu izstrādei, pateicoties ilgstošai bistabilitātei, augstai gaismas caurlaidībai caurspīdīgā stāvoklī, zemai gaismas caurlaidībai gaismu izkliedējošā stāvoklī un zemajiem energoresursu patēriniiem.

Bistabilo SmA LCD pārslēgšanās starp izkliedējošu (ieslēgtu) un caurspīdīgu (izslēgtu) stāvokli notiek ar dažādu frekvenču palīdzību. Pētījuma ietvaros tika veikti frekvenču, gaismas caurlaidības un pārslēgšanās ātruma mērījumi, efektīvāko pārslēgšanās frekvenču diapazonu noteikšanai. Displeja patērētās strāvas mērījumi izmantojot un neizmantojot papildus strāvu ierobežojošas pretestības, minimālās un maksimālās displeja patērētās jaudas noteikšanai. Izdarīti secinājumi par iegūtajiem rezultātiem, izteikti priekšlikumi turpmākajiem pētījumiem.

26.03.2018. 